\title{
Molecular Detection of Antibiotic Resistance Genes in Identified Coagulase Negative Staphylococci from Chickens Flocks and Hatcheries in Egypt.
}

\author{
Mariam-Shokery H.M.", I.A. H. Redwan"*, Wafaa A. Abd El-Ghany ${ }^{* * *}$ and M.M. \\ Amer $^{* * * *}$ \\ * MVSc student, Poultry Diseases Department, Faculty of Veterinary Medicine, Cairo \\ University ** Bacteriology, Mycology and Immunology Department, Facult. of Veterinary \\ Medicine, Bani-Suif University and ***Poultry Diseases Department, Faculty of Veterinary \\ Medicine, Cairo University, Cairo, Egypt.
}

\begin{abstract}
THE COLLECTED 942 samples (6 organ/bird) from 157 birds taken from 34 broiler chicken farms aged 2- 31 days including 13 and 21 clinical diseased and apparently health flock as well as 221 hatchery samples. Samples were tested for isolation of Coagulase negative staphylococcus (CoNS).

Results of isolation from chicken flocks with clinical signs are 9/13(69.23\%) were positive. Positive samples $(11 / 354,3.11 \%)$ including : 3liver, 4 kidney, 2 intestine, 1 air sac and 1 nasal sinus. Out of apparent healthy flocks $8 / 21$ (38.95\%) were positive. Positive samples (15/588, $2.55 \%$ ) including 3 liver, 2 kidney, 4 intestine, 3 lung, 2 air sac and 1 nasal sinus. Results showed that 15 positive flocks out of 34 flocks (34.09\%) with 26 Staphylococcus isolates from 942 samples (2.77\%) including 6 liver, 6 kidney, 6 intestine, 4 lung, 2 air-sacs and 2 nasal sinus with rate of $3.82 \%, 3.82 \%, 3.82 \%, 2.55 \%, 1.27 \%$ and $1.27 \%$; respectively. Also 12 isolates out of $26(46.15 \%)$ were CoNS include $8 \mathrm{~S}$. xylosus $(75 \%), 2 \mathrm{~S}$. scuiri $(16.67 \%)$ and $2 \mathrm{~S}$. lentus $(16.67 \%)$.
\end{abstract}

Hatchery samples reveals the isolation of 26 staphylococcus isolates $(11.76 \%)$. The tested 108 fertile eggs and dead in shell embryos resulted in 14 and 12 isolates in rate of $12.96 \%$ and $13.79 \%$; respectively. Ten isolates were CoNS (38.46\%) and represented $4.52 \%$ out of total samples including $8 \mathrm{~S}$. xylosus and $2 \mathrm{~S}$. scuiri. Eight S. xylosus was $6(5.55 \%)$ from infertile eggs and $2(2.29 \%)$ from dead in shell, While the 2 S. scuiri $(1.85 \%)$ were obtained from infertile eggs.

The tested CoNS isolates showed $100 \%$ resistance to Oxytetracycline $30 \mu \mathrm{g} / \mathrm{ml}$ (T30), Trimethoprime + Sulphamethexole 2.25/23.75 $\mu \mathrm{g} / \mathrm{ml}$ (SXT), Calindamycin $2 \mu \mathrm{g} / \mathrm{ml}$ (DA) and Oxacillin $30 \mu \mathrm{g} / \mathrm{ml}(\mathrm{OX})$. All isolates were 100\% susceptible to Vancomycin $30 \mu \mathrm{g} /$ $\mathrm{ml}$ (VA) and 90\% susceptibility to Enrofloxacin $5 \mu \mathrm{g} / \mathrm{ml}$ (ENR). Multidrug resistance was detected in form of resistance to 9,4 and 5 out of tested 13 antibiotics in $2 \mathrm{~S}$.lentus , $5 \mathrm{~S}$. scuiri and 15 S. xylosis; respectively.

Ten isolates were tested for the presence of 7 resistance gens including: mecA, tetK, blaZ , kan , ermC, icaD, bab gene. Seven isolates from the tested $10(70 \%)$ having 4 resistance gens. The most detected gens are mecA tetK, blaZ and ermC where it was detected in 90, 80, 60 and $90 \%$ respectively. Kan, icaD and bab gens were detected in rate of 30.0 and $0 \%$; respectively.

In conclusion: CoNS could isolated from healthy and diseased chicken flocks as well as from chicken hatchery. The obtained isolates were multidrug either phenotypic and /or genotypic resistant. Good hygienic measures in both chicken farms and hatchery with monitoring of drug resistance of CoNS those act as source for resistance genes to bacterial pathogens and their importance to the poultry and public health are recommended.

Keywords: Broilers, Hatcheries, CoNS, Antimicrobial susceptibility, PCR. resistance genes.

Corresponding Author: e-mail: shokrymariam@gmail.com

DOI: 10.21608/ejvs.2018.3258.1034

C2017 National Information and Documentation Centre (NIDOC) 


\section{Introduction}

Bacterial organisms of the genus Staphylococcus are non-motile, non-spore forming, glucose fermenting, and catalase producing [1] .Staphylococcus is one of the most prevalent pathogens in both humans and animals [2]. Coagulase-negative staphylococci (CoNS), including many species such as S. hyicus [3], S. gallinarum [4], S.xylosus and S. epidermidis $[5,6]$, and commonly been isolated from the nares and skin of healthy chickens, and their taxonomic positions were discussed apart from the pathogenicities. CoNS had been isolated from frozen and chilled industrialized, uncooked chicken parts or entire carcasses [7], raw chicken's meat $[8,9]$, meat product $[10]$, cooked chicken products [11], breast, neck and wing of chickens [12], chicken carcasses herd-wise pooled neck skin samples [13] as well as poultry bioaerosol [14].

Although CoNS in chickens have generally been accepted as harmless inhabitants, it has gradually become clear that they manifest pathogenicity under suitable conditions. From dermatitis and tenosynovitis, CoNS species of $S$. hyicus, S.sciuri, S. simulans and S. epidermidis were isolated. Those CoNS infections in chickens appear to be opportunistic. CoNS infections in chickens are considered to be opportunistic $[15,16]$.

In the last decade, CoNS have developed resistance to multiple antibiotics $[17,18]$. Strains of CoNS of both animal and human origins are believed to serve as important reservoirs of antimicrobial resistance genes [19]. Genes encoding antibiotic resistance are usually located on mobile genetic elements, allowing their horizontal transfer to pathogenic staphylococci [20].

The present study is an attempt for isolation, identification and study Antibiotic resistance phenotype and Molecular detection of resistance genes in CoNS from chickens flocks and hatcheries in Egypt

\section{Material and Methods}

\section{Samples}

Samples were collected from El-Fayoum, Bani Suief, El-Minia and Giza Egyptian governorates during 2016-2017. Total number of 157 birds were collected from 34 broiler chicken farms (13 clinical diseased and 21 apparently health) aged
2- 31 days. Organs including kidney, intestine, liver, nasal sinus, lung and air sac were collected from each bird with total number of 942 organs. Diseased chickens were suffered from signs varied from whitish diarrhea, nasal discharge, sneezing, coughing, gasping to swollen head as well as retarded growth. A total number of 221 samples were collected including 26 swabs from hatcheries and incubators, 108 non fertile eggs and 87 dead in shell embryo. The samples were labeled, transported in sterile plastic bags to the laboratory and kept in refrigerator at $2-5{ }^{\circ} \mathrm{C}$ till examination.

\section{Isolation and identification}

Cultivation of samples for isolation of Staphylococci species was performed according to El Seedy et al. [21]. Colonial morphology on different media including; tryptone soya broth and agar, mannitol salt agar, blood agar, Congo red and Baird-Parker media was observed after incubation at $37^{\circ} \mathrm{C}$ for $24-48$ hours [22] . Morphological identification of Staphylococci species was done using Gram's stain [23] . Biochemical identification of Staphylococcus sp. using INTEGRAL SYSTEM STAFILOCOCCHI kit [24] (. Further confirmation was achieved by the API (BioMerieux SA) kit.

\section{Antimicrobial susceptibility test}

In vitro antibiotic sensitivity test for Staphylococci strains was performed using Mueller Hinton agar (Oxoid) plates and antibiotic discs of 13 chemotherapeutic agents by disc diffusion technique [25]. The strains were cultivated on Mueller Hinton agar, and then the antibiotic discs were located by means of a dispenser. After incubation at $37^{\circ} \mathrm{C}$ for $24 \mathrm{hrs}$, the strains were evaluated as sensitive, intermediate and resistant by measuring inhibition zones diameters around the antibiotic discs $[25,26]$.

\section{Chemotherapeutic agents}

The used antimicrobial agents and their corresponding concentrations were as follows: Cefatoxaime $30 \mu \mathrm{g} / \mathrm{ml}$ (CTX), Enrofloxacin $5 \mu \mathrm{g} / \mathrm{ml}$ (ENR), Amoxicillin+Clavulanic acid $30 \mu \mathrm{g} / \mathrm{ml}$ (AMC), Vancomycin $30 \mu \mathrm{g} / \mathrm{ml}$ (VA), Oxacillin $30 \mu \mathrm{g} / \mathrm{ml}(\mathrm{OX})$, Kanamycin $30 \mu \mathrm{g} / \mathrm{ml}$ (K), Calindamycin $2 \mu \mathrm{g} / \mathrm{ml}$ (DA), Ceperazone 2 $\mu \mathrm{g} / \mathrm{ml}$ (CFP), Trimethoprime+Sulphamethexole $2.25 / 23.75 \mu \mathrm{g} / \mathrm{ml} \quad(\mathrm{SXT}), \quad$ Chloramphenicol $30 \mu \mathrm{g} / \mathrm{ml}$ (C30), Cefapime $30 \mu \mathrm{g} / \mathrm{ml}$ (FEP), Oxytetracycline $30 \mu \mathrm{g} / \mathrm{ml}$ (T30) and Gentamycin $10 \mu \mathrm{g} / \mathrm{ml}(\mathrm{CN})[26]$. 


\section{Detection of antibiotic resistance genes PCR}

Molecular detection of antibiotic resistance genes of the isolates was done. Extraction of DNA from samples was performed using the QIAamp DNA Mini Kit (Catalogue number 51304). The QIAampDNAMini Kitprovided silica-membranebased nucleic acid purification from different types of samples. The spin-column procedure did not require mechanical homogenization, so total hands-on preparation time was only 20 minutes. Ethanol 96\% (Applichem) was added to the lysate and vortexed. The sample was washed and centrifuged according to the manufacturer's instructions. DNA was eluted with $100 \mu \mathrm{l}$ of elution buffer supplied in the kit. Used primers for identification of resistance genes in CoNS are presented PCR in Table 1. Temperature and time of amplification conditions of the primers during PCR are shown in Table 2. Analysis of the PCR products in Agarose gel electrophoresis was done as Sambrook et al. [27].

\section{Results and Discussion}

Staphylococcus is one of the most prevalent pathogens in both humans and animals [2]. CoNS in chickens gradually become clear that they manifest pathogenicity under suitable conditions. The bacteriologically tested organ samples revealed the presence of staphylococci those showed typical morphological characters on used sold media and Biochemical reaction $[1,28]$ as well as Gram- positive stain [29].

Total positive samples were 26 from 942 samples $(2.77 \%)$ including 6 Liver, 6 Kidney, 6 Intestine, 4 Lung, 2 Air-sacs and 2 Nasal sinus with percentage of $3.82 \%, 3.82 \%, 3.82 \%, 2.55 \%$, $1.27 \%$ and $1.27 \%$; respectively. The result agree with the obtained 197 isolates were identified from 50 coetaneous specimens from 5-week-old normal broilers by Scanlan and Hargis [16].

Results of isolation from chicken flocks with clinical signs (Table3) showing 9/13(69.23\%) flocks were positive, with 11/354 ( $3.11 \%$ ) samples were positive. It was reported that Staph was isolated from different disease conditions in chickens including celluilitis lesions in broiler chickens [30], clinical respiratory signs in layer [31] and ducklings exhibiting tremor [32].

Positive samples including : 3liver, 4 kidney, 2 intestine, 1 air sac and 1 nasal sinus. Previous work showing that CoNs was recovered from nares, blood, liver, and hock joint [33] from poultry carcasses (35 liver, 35 skin, and 30 intestine).

Isolation from healthy chicken flocks (Table3) showing 8/21 (38.95\%) flocks were positive, 15/ 588 (2.55\%). Similar results as CoNS isolates from healthy [34]. , cutaneous specimens from 5 -week-old normal broilers [16] from 1- to 8 -week-old healthy chickens in three flocks [35]. Positive samples including 3 liver , 2 kidney, 4 intestine, 3 lung , 2 air sac and 1 sinus. The result agree with the reported isolation from chicken organs including the nares, nasal swabs and sinus $[36,37]$; liver [33,37] ; intestine and cloacal swabs [37,38] and internal organs [39,40] ). While Nawaz et al .[39] and Aarestrup et al. [40] reported isolation from hock joints.

Hatchery samples (Table 3) showing the isolation of 26 staphylococcus isolates (11.76\%). The tested 108 fertile eggs and dead in shell embryos resulted in 14 and 12 isolates in rate of $12.96 \%$ and $13.79 \%$; respectively. staphylococcus was isolated (13.3\%) from surfaces and contents of Japanese quail eggs [41], 75\% of isolates from egg shell and yolk [42] also, isolated in rate of $21.67 \%$ (78/360) including $23.12 \%$ from 160 dead in shell and $20.5 \%$ from 200 one day old chick [18].

Identification of CoNS species from broiler chicken flocks and hatchery biochemically [28] INTEGRAL SYSTEM STAPHYLOCOCCI KIT was used [24]. All Staphylococci isolates were oxidase negative, catalase positive [28] and coagulase negative $[8,43]$.

Staphylococcus isolated from chicken's organs $12 / 26$ proved to be CoNS in rate of $46.15 \%$. This result agree with Awan and Matsumoto [33] reported the prevalence of CNS in broiler farms. Isolates from the blood, liver, and hock joint were 79 Staphylococcus, 77 among of them were CoNS. Kaszanyitzky et al. [44] recovered $61.7 \%$ CNS out of recovered strains while Lazarovich et al. [45] investigated 10\% CoNS. The incidence of CoNS species from chicken's (Table 4) showing that the 12 CoNS include 8 S. xylosus $(75$ $\%), 2$ S. scuiri $(16.67 \%)$ and 2 S. lentus $(16.67 \%)$. Our result agree with $1 S$. sciuri and $7 S$. lentus were isolated from healthy and sick poultry [34]. Two $S$. lentus were identified from scabby-hip lesions in broiler chickens [16], CNS were 19\% S. lentus, $18 \%$ S. simulans, $13 \%$ S. cohnii $10 \%$ S. gallinarum and 7 $\%$ S. captis [33]. 
TABLE 1. Primers used in molecular identification of resistance genes in CoNS isolates using PCR

\begin{tabular}{|c|c|c|c|}
\hline Primer & Sequence & $\begin{array}{c}\text { Amplified } \\
\text { product }\end{array}$ & Reference \\
\hline mecA & $\begin{array}{l}\text { GTA GAA ATG ACT GAA CGT CCG ATA A } \\
\text { CCA ATT CCA CAT TGT TTC GGT CTA A }\end{array}$ & $310 \mathrm{bp}$ & McClure et al., 2006 \\
\hline ermC & $\begin{array}{l}\text { ATCTTTGAAATCGGCTCAGG } \\
\text { CAAACCCGTATTCCACGATT }\end{array}$ & 299 bp & Schlegelova et al., 2008 \\
\hline tetK & $\begin{array}{l}\text { GTAGCGACAATAGGTAATAGT } \\
\text { GTAGTGACAATAAACCTCCTA }\end{array}$ & $360 \mathrm{bp}$ & Duran et al., 2012 \\
\hline blaZ & $\begin{array}{l}\text { ACTTCAACACCTGCTGCTTTC } \\
\text { TGACCACTTTTATCAGCAACC }\end{array}$ & $173 \mathrm{bp}$ & Duran et al., 2012 \\
\hline Kan & $\begin{array}{l}\text { GTGTTTATGGCTCTCTTGGTC } \\
\text { CCGTGTCGTTCTGTCCACTCC }\end{array}$ & $621 \mathrm{bp}$ & Frana et al., 2001 \\
\hline $\mathrm{icaD}$ & $\begin{array}{l}\text { AAA CGT AAG AGA GGT GG } \\
\text { GGC AAT ATG ATC AAG ATA }\end{array}$ & $381 \mathrm{bp}$ & Ciftci et al., 2009 \\
\hline bab & $\begin{array}{l}\text { CCCTATATCGAAGGTGTAGAATTG } \\
\text { GCTGTTGAAGTTAATACTGTACCTGC }\end{array}$ & $971 \mathrm{bp}$ & Cucarella et al., 2001 \\
\hline
\end{tabular}

TABLE 2. Temperature and time conditions of the primers for Staphylococci identification during PCR according to Emerald Amp GT PCR Master Mix (Takara) kit.

\begin{tabular}{|c|c|c|c|c|c|c|}
\hline Gene & $\begin{array}{c}\text { Primary } \\
\text { denaturation }\end{array}$ & $\begin{array}{c}\text { Secondary } \\
\text { denaturation }\end{array}$ & Annealing & Extension & $\begin{array}{l}\text { No. of } \\
\text { cycles }\end{array}$ & $\begin{array}{c}\text { Final } \\
\text { extension }\end{array}$ \\
\hline mecA & $\begin{array}{l}94^{\circ} \mathrm{C} \\
5 \mathrm{~min} .\end{array}$ & $\begin{array}{c}94^{\circ} \mathrm{C} \\
30 \mathrm{sec} .\end{array}$ & $\begin{array}{c}50^{\circ} \mathrm{C} \\
30 \mathrm{sec} .\end{array}$ & $\begin{array}{c}72^{\circ} \mathrm{C} \\
30 \mathrm{sec} .\end{array}$ & 35 & $\begin{array}{l}72^{\circ} \mathrm{C} \\
7 \mathrm{~min} .\end{array}$ \\
\hline ermC & $\begin{array}{l}94^{\circ} \mathrm{C} \\
5 \mathrm{~min} .\end{array}$ & $\begin{array}{c}94^{\circ} \mathrm{C} \\
30 \mathrm{sec} .\end{array}$ & $\begin{array}{c}51^{\circ} \mathrm{C} \\
30 \mathrm{sec} .\end{array}$ & $\begin{array}{c}72^{\circ} \mathrm{C} \\
30 \mathrm{sec} .\end{array}$ & 35 & $\begin{array}{l}72^{\circ} \mathrm{C} \\
7 \mathrm{~min} .\end{array}$ \\
\hline blaZ & $\begin{array}{l}94^{\circ} \mathrm{C} \\
5 \mathrm{~min} .\end{array}$ & $\begin{array}{c}94^{\circ} \mathrm{C} \\
30 \mathrm{sec} .\end{array}$ & $\begin{array}{c}54^{\circ} \mathrm{C} \\
30 \mathrm{sec} .\end{array}$ & $\begin{array}{c}72^{\circ} \mathrm{C} \\
30 \mathrm{sec} .\end{array}$ & 35 & $\begin{array}{l}72^{\circ} \mathrm{C} \\
7 \mathrm{~min} .\end{array}$ \\
\hline Kan & $\begin{array}{l}94^{\circ} \mathrm{C} \\
5 \mathrm{~min} .\end{array}$ & $\begin{array}{c}94^{\circ} \mathrm{C} \\
30 \mathrm{sec} .\end{array}$ & $\begin{array}{c}54^{\circ} \mathrm{C} \\
45 \mathrm{sec} .\end{array}$ & $\begin{array}{c}72^{\circ} \mathrm{C} \\
45 \mathrm{sec} .\end{array}$ & 35 & $\begin{array}{c}72^{\circ} \mathrm{C} \\
10 \mathrm{~min} .\end{array}$ \\
\hline bab & $\begin{array}{l}94^{\circ} \mathrm{C} \\
5 \mathrm{~min} .\end{array}$ & $\begin{array}{c}94^{\circ} \mathrm{C} \\
30 \mathrm{sec} .\end{array}$ & $\begin{array}{c}58^{\circ} \mathrm{C} \\
45 \mathrm{sec} .\end{array}$ & $\begin{array}{l}72^{\circ} \mathrm{C} \\
45 \mathrm{sec} .\end{array}$ & 35 & $\begin{array}{c}72^{\circ} \mathrm{C} \\
10 \mathrm{~min}\end{array}$ \\
\hline
\end{tabular}

TABLE 3. Incidence of Staphylococci species from chicken organs ( $n=157$ each) and hatchery samples $(n=221)$.

\begin{tabular}{|c|c|c|c|c|c|c|c|c|c|}
\hline \multicolumn{5}{|l|}{ Chicken } & \multicolumn{5}{|c|}{ Hatcheries } \\
\hline \multirow{2}{*}{$\begin{array}{l}\text { Samples } \\
\text { Type }\end{array}$} & \multicolumn{2}{|c|}{ No of positive samples } & \multicolumn{2}{|c|}{ Total } & \multicolumn{3}{|c|}{ Samples } & \multicolumn{2}{|c|}{ No of isolates } \\
\hline & $\begin{array}{c}\text { Diseased } \\
\text { flocks }\end{array}$ & $\begin{array}{c}\text { healthy } \\
\text { flocks }\end{array}$ & $\begin{array}{c}\text { No. of } \\
\text { Isolates }\end{array}$ & $\%$ & Type & Total number & & no & $\%$ \\
\hline Liver & 3 & 3 & 6 & 3.82 & Walls & 26 & & 0 & \\
\hline Kidney & 4 & 2 & 6 & 3.82 & Infertile eggs & 108 & & 14 & 12.96 \\
\hline Intestine & 2 & 4 & 6 & 3.82 & Dead in shell & 87 & & 12 & 13.79 \\
\hline Lung & 2 & 3 & 4 & 2.55 & & & & & \\
\hline Air-sacs & 1 & 2 & 2 & 1.27 & & & & & \\
\hline Nasal sinus & 1 & 1 & 2 & 1.27 & & & & & \\
\hline Total & 11 & 15 & 26 & & & 221 & 26 & & \\
\hline $\begin{array}{l}\text { Over all } \\
\text { total }\end{array}$ & $\begin{array}{c}11 / 354 \\
(3.11 \%)\end{array}$ & $\begin{array}{c}15 / 588 \\
(2.55 \%)\end{array}$ & $26 / 942$ & 2.77 & $26 / 221$ & & & & 11.76 \\
\hline
\end{tabular}

Egypt. J. Vet. Sci. Vol. 49, No.1 (2018) 
TABLE 4. Incidence of CoNS isolates species from chicken organs ( $\mathrm{n}=157 \mathrm{each}$ ) and hatcheries.

\begin{tabular}{|c|c|c|c|c|c|c|c|c|c|c|c|c|}
\hline \multicolumn{7}{|c|}{ Chicken organs } & \multicolumn{6}{|c|}{ Hatcheries } \\
\hline \multirow{3}{*}{$\begin{array}{l}\text { Samples } \\
\text { Type }\end{array}$} & \multicolumn{6}{|c|}{ CoNS species } & \multicolumn{2}{|c|}{ Samples } & \multicolumn{4}{|c|}{ CoNS species } \\
\hline & \multicolumn{2}{|c|}{ S. xylosus } & \multicolumn{2}{|c|}{ S. scuiri } & \multicolumn{2}{|c|}{ S. lentus } & \multirow[t]{2}{*}{ Type } & \multirow[t]{2}{*}{ No } & \multicolumn{2}{|c|}{ S. xylosus } & \multicolumn{2}{|c|}{ S. scuiri } \\
\hline & No. & $\%$ & No & $\%$ & No & $\%$ & & & No & $\%$ & No & $\%$ \\
\hline Liver & 4 & 3.18 & 0 & 0 & 0 & 0 & Walls & 26 & 0 & 0 & 0 & 0 \\
\hline Intestine & 0 & 0 & 2 & 1.27 & 2 & 1.27 & Infertile eggs & 108 & 6 & 5.55 & 2 & 1.85 \\
\hline Lung & 2 & 1.27 & 0 & 0 & 0 & 0 & Dead in shell & 87 & 2 & 2.29 & 0 & 0 \\
\hline Air-sacs & 2 & 1.27 & 0 & 0 & 0 & 0 & & & & & & \\
\hline Total & 8 & & 2 & & 2 & & & 221 & 8 & & 2 & \\
\hline $\begin{array}{l}\text { Over all } \\
\text { total }\end{array}$ & \multicolumn{6}{|c|}{$12 / 942(1.27 \%)$} & & \multicolumn{5}{|c|}{$10 / 221(4.42 \%)$} \\
\hline
\end{tabular}

TABLE 5. Rate of CoNS susceptibility to used antibiotics.

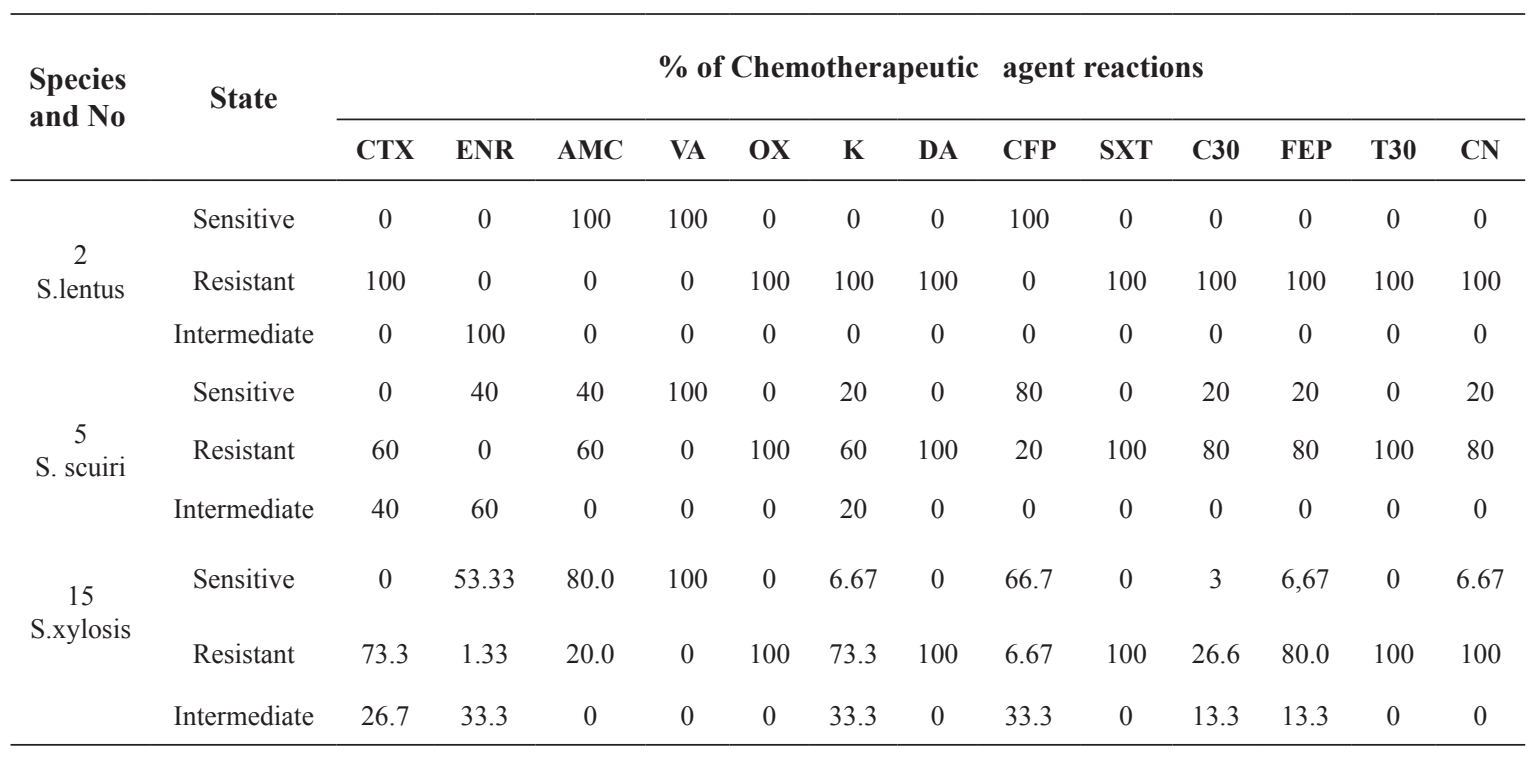

Eight $S$. xylosus strains were isolated as 4,2 from lung and 2 from air-sacs in rate of $3.18 \%$, $1.27 \%$ and $1.27 \%$ out of tested samples [24,31]. Two $S$. scuiri as well as 2 S. lentus were isolated only from intestine 2 out of 157 samples (1.27\%) [24,38]. From a total 26 samples; 10 isolates were CoNS (38.46\%) and represented $4.52 \%$ out of total samples $[33,45]$. CONS including $8 \mathrm{~S}$. xylosus and 2 S. scuiri. Eight S. xylosus were 6 $(5.55 \%)$ from infertile eggs and $2(2.29 \%)$ from dead in shell, While the 2 S. scuiri $(1.85 \%)$ were obtained from infertile eggs (Table 4) $[18,41,42]$.

The tested CoNS isolates susceptibility against 13 different available antimicrobial using disk diffusion method (Table14) [10,46]. Results of antibiotic susceptibility showed $100 \%$ resistance to Oxytetracycline $30 \mu \mathrm{g} / \mathrm{ml}$, Trimethoprime + Sulphamethexole 2.25/23.75 $\mu \mathrm{g} / \mathrm{ml}$ (SXT) , Calindamycin $2 \mu \mathrm{g} / \mathrm{ml}$. and Oxacillin $30 \mu \mathrm{g} /$ $\mathrm{ml}$. The tetracycline resistance can be supported by those reported as $23 \mathrm{CNS}$ were tetracycline resistant [40], coagulase positive and negative Staphylococci isolated from broiler farm in Ismailia province (Egypt) Complete antibiotic resistance to oxytetracycline [47] and high levels of resistance towards tetracycline, oxytetracycline [48]. 
Different levels of resistance were also detected $67 \cdot 8 \%$ [49] $22 \%$ of S. xylosus [20,50] $29.1 \%$ [12] $18.4 \%$ S. scuiri, S. lentus, and $S$. epidermidis isolates [13] and $21.4 \%$ out of 84 S. xylosus isolates from poultry bioaerosol were resistant to tetracycline [14]. While Aslantaş et al. [51] investigated that 89 isolates of (CNS) susceptible to Tetracycline $(100 \%)$. Osman et al. [52] reported that $36 \mathrm{CNS}$ isolates recovered from chicken meat showed complete resistance to Sulfamethoxazole/Trimethoprim. Aslantaş et al. [51] investigated $69.2 \%$ out of 89 isolates CNS were resistant while $2.6 \%$ of $S$. scuiri, S. lentus, and $S$. epidermidis were resistant by Huber et al. [11]. Resistance to Clindamycin was reported [52, 53]. Complete resistance to Oxacillin was also reported [14, 18, 52] while Piessens et al. [54] found $42.9 \%$ resistance.

All isolates were $100 \%$ susceptible to Vancomycin $30 \mu \mathrm{g} / \mathrm{ml}$ (VA) and showed 90\% susceptibility to Enrofloxacin $5 \mu \mathrm{g} / \mathrm{ml}$ (ENR). While the tested isolates showed variable susceptibility to the other used antibiotics. The $100 \%$ susceptibility to Vancomycin was determined [33,32, 55]. Susceptibility of CoNS to Enrofloxacin was found to be $100 \%[18,33]$ while Youssef and Hamed [47] detected sensitivity of the isolates to Enrofloxacin was $60 \%$. Drug susceptibility (Table 5) of the tested CoNS isolate multidrug resistance was detected as 2 S.lentus, 5 S. scuiri and 15 S. xylosis were resistant to 9, 4 and 5 out of tested 13 antibiotics; respectively. This result indicated that the isolates are multiresistant to antibiotics. Same results CoNS isolates recovered from chickens were reported including S. sciuri, S. lentus and S. xylosus
$[53,56]$. Moreover, Chah et al. [57] reported that $81.3 \%$ of the CoNS were multi-drug resistance.

Phenotypic resistances were verified by PCR amplification and could be traced back to the genes $[10,58]$. Results of PCR tested isolates proved that 7 isolates from the tested $10(70 \%)$ each having 4 resistance genes (Table 6). This result proved that drug resistance can depend on other factors rather than the genetic one. This result can agree with Zdolec et al. [59] in assessment of antimicrobial susceptibility of CNS $23.6 \%$ CNS isolates were found to be resistant to oxacillin. All isolates phenotypic resistant to oxacillin did not have the mecA gene, which was only found in $14.6 \%$ of the isolates. Also, Osman et al. [52] detected that $85.7 \%$ of CNS species phenotypic resistant to oxacillin expressed the mecA gene.

The most genes are mecA, tetK, blaZ and ermC (Fig 1-7). Results agreed with Zdolec et al. [59] assessed the antimicrobial susceptibility of CNS Isolates were tested for sensitivity to Vancomycin, Ampicillin, Erythromycin, Tetracycline, Gentamycin and Oxacillin. PCR was used for the detection of resistance genes mecA, erm B, tet $\mathrm{K}$ and tet $\mathrm{M}$. Molecular evaluation of resistance determinants revealed tet $\mathrm{K}$ or Tet $\mathrm{M}$ genes in $8 \mathrm{~S}$. epidermidis strains. Vela et al. [14] confirmed the presence of tetK, ermB, and blaZ genes in $\mathrm{S}$. xylosis isolates that found resistant to tetracycline, erythromycin, and $\beta$-lactam antibiotics. Chah et al [57] found that resistance genes detected were: blaZ, tet $(\mathrm{K})$, tet $(\mathrm{M})$, tet $(\mathrm{L})$, erm (B), lnu (A), aacA-aphD, aphA3, str, dfr (G), cat $\mathrm{pC} 221$, and cat $\mathrm{pC} 223$.

TABLE 6. Resistance genes in MDRCoNS using PCR.

\begin{tabular}{|c|c|c|c|c|c|c|c|c|}
\hline Sample & \multicolumn{7}{|c|}{ Gene } & No of gens \\
\hline 1 & + & - & - & + & + & - & - & 3 \\
\hline 2 & + & + & + & - & + & - & - & 4 \\
\hline 3 & + & + & - & + & + & - & - & 4 \\
\hline 6 & + & + & + & - & + & - & - & 4 \\
\hline 7 & + & + & - & - & + & - & - & 3 \\
\hline 8 & + & + & + & - & + & - & - & 4 \\
\hline 9 & - & + & + & + & + & - & - & 4 \\
\hline 10 & + & - & - & - & - & - & - & 1 \\
\hline
\end{tabular}

Egypt. J. Vet. Sci. Vol. 49, No.1 (2018) 


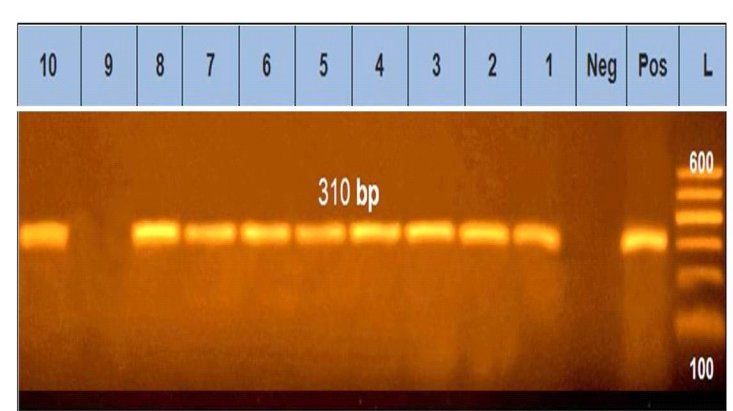

Fig. (1): Lane L: Molecular size marker (100-600 pb). The expected amplicon size of mect gene $310 \mathrm{pb}$. Lanes $1,2,3,4,5,6,7,8$ and 10 are positive escept lane 9 is neggative.

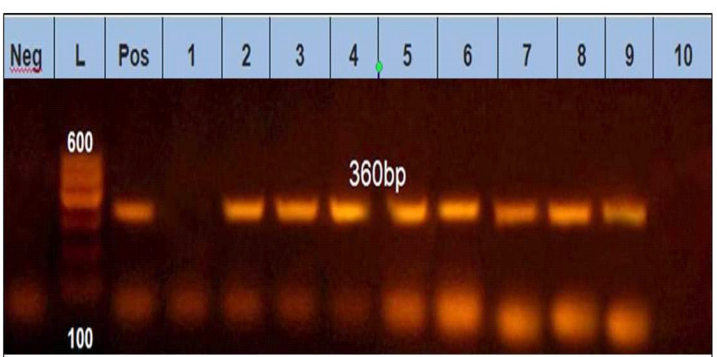

Fig. (3): Lane L: Nolecular size markiker (100-6000 pb). The espected amplicon size of teth gene at $310 \mathrm{pb}$. Lames 1 and 10 are neggative while lanes $2,3,4, j, 6,7,8$ and 9 are positive.

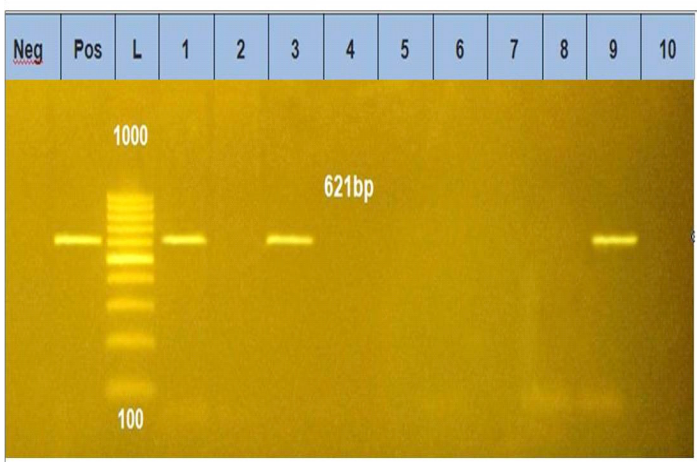

Fig. (5): Lane L: Nolecular size markiker (100-1000 ph). The erpected amplicon size of kiun gene at 621 ph. Lane 1,3 and 9 are positive, while lanes $2,4,5,6,7,8$ and 10 are negative.

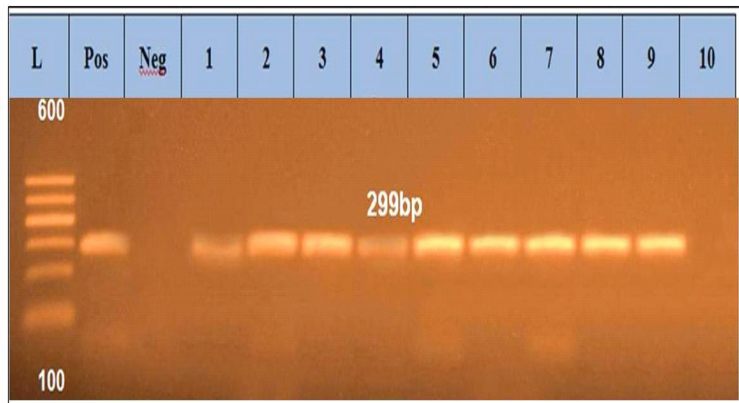

Fig., (2): Lane L: Volecular size markiker (100-600 pb). The espected amplicon size of ermc coene at 299 ph, Lannes 1,2,3,4,5,6,7,8 and $9(10)$ are positive escept lane 10 (2) is negagative.

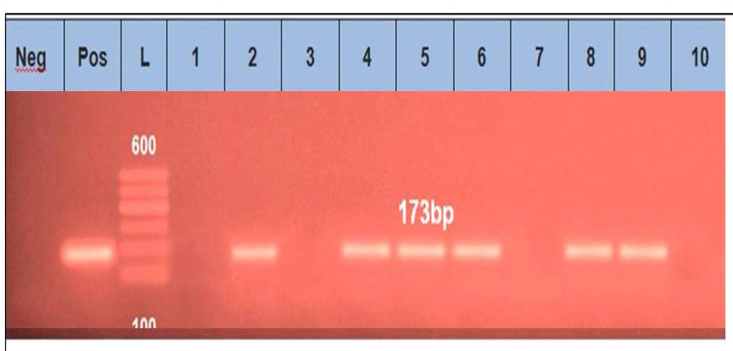

Fig. (f): Lane L: Molecular size marker (100-600 pb). The expected amplicon size of bla gene at 173 pb.Lanes 1,3,7 and 10 are negative, but lanes 2, 4,5,6,8 and 9 are positive.

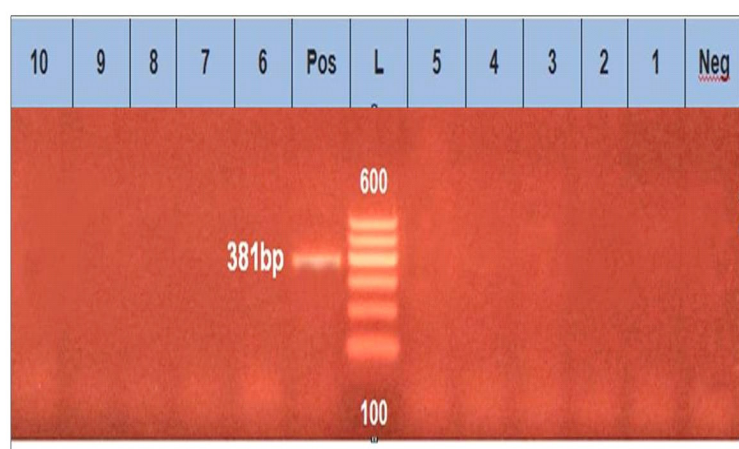

Fig. (6): Lane L: molecular size marker (100-600 pb). The expected amplicon size of $i c a l$ gene at 381 ph. Lanes $1,2,3,4,5,6,7,8,9$ and 10 are negative.

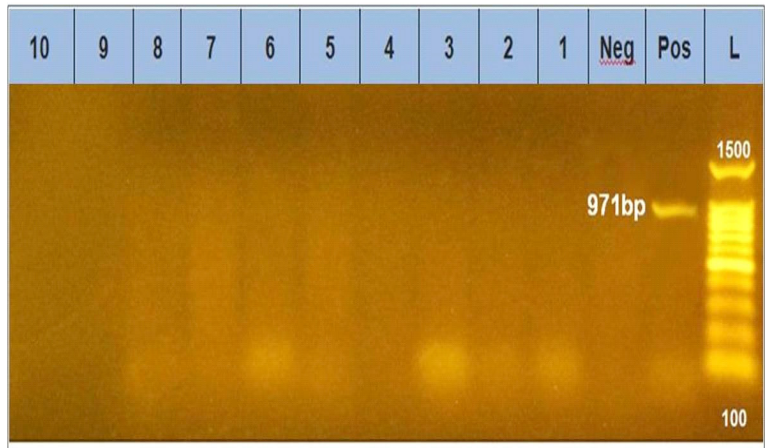

Fig. (7): Lane L: molecular size marker (100-1500 pb). The expected amplicon size of bab gene at 971 pb. Lanes $1,2,3,4,5,6,7,8,9$ and 10 are neggative. 
Rate of detected genes are mecA, tetK, blaZ and ermC where it was detected in 90, 80, 60 and $90 \%$; respectively. Kan, icaD and bab genes were detected in rate of 30.0 and $0 \%$ respectively. The detected $90 \%$ mecA was reported by Wang et al. [38] identified 95\% oxacillin-resistant isolates harbored the mecA gene, also erm (C), erm (B), and aacA-aphD were detected. Al-Muhanna [60] and Chajęcka-Wierzchowska et al. [53] detected that $100 \%$ isolates of CNS carried mec A gene and $85.7 \%$ [52]. While, lower rates $68.7 \%$ by Bhargava and Zhang [49], and $6.7 \%$ by Han et al. [53] could be assessed in oxacillin resistant isolates. Tetracycline resistant gene etKwas detected in $80 \%$. This result is close to $100 \%$ $[50,40]$ where all tetracycline resistant CoNS contained the tet $(\mathrm{K})$ gene. While Podkowik et al. [61] reported $60 \%$ and $61 \%$ tet( $(\mathrm{M})$ by Bhargava and Zhang [49]. Penicillin resistance blaZ was detected in $60 \%$ of isolates while Podkowik et al. [61] reported $92 \%$ penicillin resistance blaZ. Regarding 90\% erythromycin resistance ermC the available literature proved rates of $100 \%$ [40] , 83.33\% [39] $56.2 \%$ [49] and 42\% [61].

This study pointed out that monitoring antibiotic resistance in specific bacteria from broiler could provide useful insight to public health and when considering that antimicrobial resistant bacteria can be disseminated in the air during poultry transportation [62].

In conclusion: CoNS were isolated from healthy and diseased chicken flocks as well as from chicken hatchery. The obtained isolates were multidrug either phenotypic and /or genotypic resistant. We recommended good hygienic measures in both chicken farms and hatchery with monitoring of drug resistance of CoNS those act as source for resistance genes to other bacterial pathogens and their importance for both poultry and public health.

\section{Acknowledgements :}

The authors appreciate the efforts of all those participated in this study.

\section{Conflict of interest :}

We certify that there is no conflict of interest with any financial organization regarding the material discussed in the manuscript.

\section{Funding statement :}

The authors declared that the work is not funded from any organization but it self-dependent.

Egypt. J. Vet. Sci. Vol. 49, No.1 (2018)

\section{References}

1. Harley J.P., Prescott L.M . Laboratoy Exercises in Microbiology. $5^{\text {th }}$ ed (2002).

2. Casey JA, Shopsin B, Cosgrove SE, Nachman KE, Curriero FC, Rose HR and Schwartz BS., Highdensity livestock production and molecularly characterized MRSA infections in Pennsylvania. Environ Health Perspect., 122 (5), 464-470 ( 2014)

3. Takeuchi, S., Y. Kobayashi, T. Morozumi, and S. Niibori. Isolation and some properties of Staphylococcus hyicus subsp. hyicus from pigs, chickens and cows. Jpn. J. Vet. Sci., 47, 841-843 (1985).

4. Devriese, L. A., B. Poutrel, R. Kilpper-Balz, and K. H. Schleifer. Staphylococcus gallinarum and Staphylococcus caprae, two new species from animals. Int. J. Syst. Bacteriol., 33,480-486. (1983).

5. Shimizu, A., Kawano, J. and Kimura S. Phage typing of coagulasenegative staphylococci isolated from various animals and humans in Japan. Jpn. J. Vet. Sci., 49, 207-215 (1987).

6. Shimizu, A., Ozaki J., Kawano J., Saitoh Y., and Kimura S. Distribution of Staphylococcus species on animal skin. J. Vet. Med. Sci., 54, 355- 357 (1992).

7. Martins, P.D., de Almeida, T.T., Basso, A.P., de Moura, T.M., Frazzon, J., Tondo, E.C. and Frazzon, A.P.G. Coagulase-Positive staphylococci isolated from chicken meat: pathogenic potential and vancomycin resistance. Food borne pathogens and disease, 10 (9), 771-776 (2013).

8. Yurdakul, N. E., ErgiNkaYa, Z. and ÜNal, E. Antibiotic Resistance of Enterococci, Coagulase Negative Staphylococci and Staphylococcus aureus Isolated from Chicken Meat. Czech J. of Food Sci., 31 (1) 14-19 (2013).

9. Aklilu, E., Nurhardy, A. D., Mokhtar, A., Zahirul, I. K., and Siti Rokiah, A. Molecular detection of methicillin-resistant Staphylococcus aureus (MRSA) and methicillin-resistant Staphylococcus epidermidis (MRSE) isolates in raw chicken meat. Internat. Food Res. J., 23 (1), 322-325 (2015).

10. Attien, P., Sina, H., Moussaoui, W., Dadié, T., Djéni, T., Bankole, H. S., and Baba-Moussa, L. Prevalence and antibiotic resistance of Staphylococcus strains isolated from meat products sold in Abidjan streets (Ivory Coast). African J. of Microbiol. Res., 7(26), 3285-3293 (2013).

11. Sharaf, E.M. and Sabra, M.S. Microbiological loads for some types of cooked chicken meat products at Al-Taif Governorate, KSA. World Applied Sci. J., 17 (5), 593-597 (2012). 
12. Citak, S. and Duman, T. Staphylococcus aureus and coagulase-negative Staphylococcus from raw chicken samples in Turkey: Prevalence and antimicrobial resistance. J. Food Agri. Environ., 9 (1), 156-58 (2011).

13. Huber, H., Ziegler, D., Pflüger, V., Vogel, G., Zweifel, C. and Stephan, R. Prevalence and characteristics of methicillin-resistant coagulasenegative staphylococci from livestock, chicken carcasses, bulk tank milk, minced meat, and contact persons. BMC Vet. Res., 7 (1), 6-10 (2011).

14. Vela, J., Hildebrandt, K., Metcalfe, A., Rempel, H., Bittman, S., Topp, E., and Diarra, M. Characterization of Staphylococcus xylosus isolated from broiler chicken barn bioaerosol. Poult. Sci., 91(12), 3003-3012 (2012).

15. Kibenge, F.S.B., Rood J.I., and Wilcox G.E. Lysogeny and other characteristics of Staphylococcus hyicus isolated from chickens. Vet. Microbiol., 8, 411-415 (1983).

16. Scanlan, C. M. and Hargis , B.M. A bacteriologic study of scabby-hip lesions from broiler chickens in Texas. J. Vet. Diagn. Invest., 1,170-173 (1989).

17. Ma, X.X., Wang, E.H., Liu, Y., \&Luo, E.J. Antibioticsusceptibility of coagulase-negative staphylococci (CoNS): emergence of teicoplaninnon-susceptible CoNS strains with inducible resistance to vancomycin. Journal of Medical Microbiol., 60 (11), 1661-1668 (2011).

18. Amer M.M., Kh. M. ELbayoumi, Zeinab M.S. Amin Girh, Hoda M. Mekky and Nagwa S. Rabie. A Study on Bacterial Contamination in dead in shell Chicken Embryos and Culled One Day Chicks Intern. J. of Pharmaceutical and Phytopharmacological Res. (eIJPPR), 7 (2) 5-11 (2017).

19. Becker, K., Heilmann C. and Peters G. CoagulaseNegative Staphylococci. Clin Microbiol Rev., 27 (4), 870-926 (2014).

20. Resch, M., Nagel, V., and Hertel, C. Antibiotic resistance of coagulase-negative staphylococci associated with food and used in starter cultures. Internat. J. of Food Microbiol., 127 (1), 99-104 (2008).

21. El Seedy, F.R., El-Shabrawy, M., Hakim, A.S., Syame, S.F. and Osman, N.M. Advanced techniques used for isolation and characterization of Staphylococcus aureus isolated from mastitic buffaloes. Global Veterinaria, 8 (2), 144-152 (2012).
22. Swayne, D.E., Charman, E., Glisson, J.R., Jackwood, M.W., Pearson, J.E. and Reed, W.M. Staphylococcosis, A laboratory manual for the of isolation and identification of avian pathogens, $4^{\text {th }}$ ed. Am. Assoc. Avian Pathol., (1998).

23. Sobhy H., Mohamed Kh. F., Essam H.M. and Soad A. Nasef, Using Integral System Stafilococchi Kit for Biochemical Identification and Susceptibility Testing of Coagulase Negative Staphylococcus Isolated from Broiler Chickens in Egypt. Global Veterinaria, 13 (6), 1022-1028 (2014).

24. CLSI. Clinical and Laboratory Standard Institute; Performance Standards for Antimicrobial Susceptibility Testing. CLSI Approved Standard. (2013).

25. Bauer, A.W., Kirby, W.M.M., Sheris, J.C. and Truk, M. Antibiotic susceptibility testing by a standardized single disc method. American Journal Clinical Pathology, 145, 225-230 (1966).

26. Sambrook, J.; Fritsch, E.F. and Maniatis, T. Molecular Cloning: a laboratory manual. $2^{\text {nd }}$ ed. Cold Spring Harbor Press, New York. (1989).

27. Quinn, P.J., Markey, B.K., Carter, M.E., Donnelly, W.J and Leonard, F.C. Veterinary Microbiology and Microbial Disease. Blackwell Science Ltd, a Blackwell Publishing Co, PP. 465-475. (2002).

28. Kawano, J., Shimizu, A., Saitoh, Y., Yagi, M., Saito, T. and Okamoto, R. Isolation of methicillinresistant coagulase-negative staphylococci from chickens. J. of Clinical Microbiol., 34 (9), 20722077 (1996).

29. Osman, J. Bacteria Associated With Avian Cellulitis In Broiler Chickens. M.Sc Thesis, Microbiology, Faculty of Vet. Med. University of Khartoum. (2002)

30. Barros, M.R., Costa, M.M.D., França, C.A.D., Saukas, T.N., da Silva, L.B., Silva, V.A.S. and Mota, R.A. Resistance of Staphylococcus spp., to antimicrobials isolated from broilers and commercial layers in the state of Pernambuco, Brazil. Pesquisa Veterinária Brasileira, 31(8), 672676 (2011).

31. Carter, G.R. and Cole, J.R. In: Diagnostic Procedures in Veterinary Bacteriology and Mycology, $5^{\text {th }}$ ed. Academic Press, New York, N.Y. (1990).

32. Han, J. E., Hwang, S. Y., Kim, J. H., Shin, S. P., Jun, J. W., Chai, J. Y., . and Park, S. C. CPRMethicillin resistant coagulase-negative staphylococci isolated from South Korean ducks exhibiting tremor. Acta Veterinaria Scandinavica, 55 (1), 55-88. (2013). doi: 10.1186/1751-0147-55-88. 
33. Awan, M. A. and Matsumoto, M. Heterogeneity of staphylococci and other bacteria isolated from sixweek-old broiler chickens. Poult. Sci., 77 (7), 944949 (1998).

34. Adegoke, G.O. Comparative characteristics of Staphylococcus sciuri, Staphylococcus lentus and Staphylococcus gallinarum isolated from healthy and sick hosts. Vet. Microbiol., 11 (1-2), 185-189 (1986).

35. Olivier, M., Veary, C.M., Cloete, T.E. and Von Holy, A. Microbiological status of selected chicken carcasses from a non automated poultry processing plant. J. of Basic Microbiol., 36, 41-49 (1996).

36. Mcnamee, P.T. and Smyth, J.A. Bacterial chondronecrosis with osteomyelitis of broiler chickens : a review. Avian Pathol., 29, 253-270 (2000).

37. Shimaa El-Nagar, Abd El-Azeem M.W., Nasef S.A, Sultan S. Prevalence of Toxigenic and Methicillin Resistant Staphylococci in Poultry Chain Production. J. Advanced Vet. Res. , 7 (2) 3338 (2017)

38. Wang, Y., He, T., Schwarz, S., Zhao, Q., Shen, $\mathrm{Z}$., Wu, C. and Shen, J. Multidrug resistance gene $\mathrm{cfr}$ in methicillin-resistant coagulase-negative staphylococci from chickens, ducks, and pigs in China. Internat. J. of Medical Microbiol., 303 (2), 84-87 (2013).

39. Nawaz, M. S., Khan, A. A., Khan, S. A., Paine, D. D., Pothuluri, J. V., and Cerniglia, C. E. Biochemical and molecular characterization of erthromycinresistant avian Staphylococcus spp. isolated from chickens. Poult. Sci., 78 (8), 1191-1197 (1999).

40. Aarestrup, F. M., Agersø, Y., Ahrens, P., Jørgensen, J.C.O., Madsen, M. and Jensen, L. B. Antimicrobial susceptibility and presence of resistance genes in staphylococci from poultry. Vet. Microbiol., 74 (4), 353-364 (2000).

41. Pyzik, E., and Marek, A. Characterization of bacteria of the genus Staphylococcus isolated from the eggs of Japanese quail (Coturnix coturnix japonica). Polish J. of Vet. Sci., 15 (4), 767-772 (2012).

42. Abdullah, I.N. Isolation and identification of some bacterial isolates from table egg. J. of Vet. Sci., 3 (2), 59-67 (2010).

43. Faria, C., Vaz-Moreira, I., Serapicos, E., Nunes, O.C. and Manaia, C.M. Antibiotic resistance in coagulase negative staphylococci isolated from wastewater and drinking water. Science of the Total Environment, 407, 3876-3882 (2009).

Egypt. J. Vet. Sci. Vol. 49, No.1 (2018)
44. Kaszanyitzky, É.J., Egyed, Z., Jánosi, S., Keserü, J., Gál, Z., Szabo, I. and Somogyi, P. Staphylococci isolated from animals and food with phenotypically reduced susceptibility to $\beta$-lactamase-resistant $\beta$-lactam antibiotics. Acta Veterinaria Hungarica, 52 (1), 7-17 (2004).

45. Lazarovich, Z., Boldur, I., Reifer, R., and Nitzan, Y. An in vitro study of adherence of coagulasenegative staphylococci to bone chip columns. Res. in Microbiol., 157 (7), 619- 624 (2006).

46. Froyman, R., Deruyttere, L. and Devriese, L.A. The effect of antimicrobial agents on an outbreak of staphylococcal dermatitis in adult broiler breeders. Avian Pathol., 11 (3), 521-525 (1982).

47. Youssef, A.I. and Hamed, D.M. Methicillin resistant Staphylococcus aureus (MRSA) associated with arthritis in broiler farms in Ismailia province, Egypt and its zoonotic potential significance. Suez Canal Vet. Med. J, 18, 309-322 (2012)

48. Van Wijk, E. The incidence of antibiotic resistant bacteria in chicken and pork (Doctoral dissertation, North-West University). (2003).

49. Bhargava, K. and Zhang, Y. Multidrug - resistant coagulase-negative Staphylococci in food animals. J. of applied Microbiol., 113(5), 10271036 (2012).

50. Koksal, F., Yasar H. and Samasti M. Antibiotic resistance patterns of coagulasenegative staphylococcus strains isolated from blood cultures of septicemic patients in Turkey Microbiological Res., 164, 404- 410 (2009).

51. Aslantaş, Ö., Yılmaz, M.A., Yılmaz, E.Ş. and Kurekci, C. Antimicrobial susceptibility pattern and SCCmec types of methicillin-resistant coagulasenegative staphylococci from subclinical bovine mastitis in Hatay, Turkey. Bull. of the Vet. Institute in Pulawy, 58 (4), 563-566 (2014).

52. Osman, K., Badr, J., Al-Maary, K.S., Moussa, I. M., Hessain, A.M., Girah, Z.M.A. and Saad, A. Prevalence of the antibiotic resistance genes in coagulase-positive-and negative-Staphylococcus in chicken meat retailed to consumers. Frontiers in Microbiology, 22 (7)1846. Collection. (2016).

53. Chajęcka-Wierzchowska W, Zadernowska A, Nalepa B, Sierpińska $M$ and LaniewskaTrokenheim L. Retail ready-to-eat food as a potential vehicle for Staphylococcus spp. harboring antibiotic resistance genes. J. Food Prot., 77 (6), 993-998 (2014). 
54. Piessens, V., De Vliegher, S., Verbist, B., Braem, G., Van Nuffel, A., De Vuyst, L., and Van Coillie, E. Characterization of coagulase-negative staphylococcus species from cows' milk and environment based on bap, icaA, and mecA genes and phenotypic susceptibility to antimicrobials and teat dips. J. Dairy Sci., 95 (12), 7027-7038 (2012).

55. De Oliveira, A., Cataneli Pereira, V., Pinheiro, L., Moraes Riboli, D. F., Benini Martins, K. and Ribeiro de Souza da Cunha, M.D.L. Antimicrobial resistance profile of planktonic and biofilm cells of Staphylococcus aureus and Coagulase-Negative staphylococci. Internat. J. Molecular Sci., 17(9), 1423. doi: 10.3390/ijms17091423 (2016).

56. Boamah, V. E., Agyare, C., Odoi, H., Adu, F., Gbedema, S. Y. and Dalsgaard, A. Prevalence and antibiotic resistance of coagulase-negative Staphylococci isolated from poultry farms in three regions of Ghana. Infection and drug resistance, 10, 175 (2017).

57. Chah, K. F., Gómez-Sanz, E., Nwanta, J. A., Asadu, B., Agbo, I. C., Lozano, C. and Torres, C. Methicillinresistant coagulase-negative staphylococci from healthy dogs in Nsukka, Nigeria. Brazilian $J$. Microbiol., 45 (1), 215-220 (2014).

58. Eady, E. A., Ross, J. I., Tipper, J. L., Walters, C. E., Cove, J. H., and Noble, W. C. Distribution of genes encoding erythromycin ribosomal methylases and an erythromycin efflux pump in epidemiologically distinct groups of staphylococci. J. of Antimicrobial Chemotherapy, 31 (2), 211-217 (1993).
59. Zdolec, N., Racic, I., Vujnovic, A., Zdelar-Tuk, M., Matanovic, K., Filipovic, I., and Spicic, S. Antimicrobial resistance of coagulase-negative staphylococci isolated from spontaneously fermented sausages. Food Technol. and Biotechnol., 51 (2), 240-246 (2013).

60. Al-Muhanna, A.S., Al-Hilu, S.A. and Alzuhairi, M.A. Characterization of coagulase-negative, oxacillin resistant staphylococci from patients undergoing catheter related infections. Eur. J. Exp. Biol., 4 (3), 774-778 (2014)

61. Podkowik, M., Bystroń, J. and Bania, J. Genotypes, antibiotic resistance, and virulence factors of staphylococci from ready-to-eat food. Foodborne pathogens and disease, 9 (1), 91-93 (2012).

62. Rule, A. M., S.L. Evans, and E.K. Silbergeld. Food animal transport: A potential source of community exposures to healthhazards from industrial farming (CAFOs). J. Infect. PublicHealth, 1, 33-39 (2008).

(Received 21/03/2018; accepted 03/05/2018) 


\section{الكثف الجزيئي للجينات المقاومة للمضادات الحيوية في المكورات العنقودية سلبية التخثر Coagulase من قطعان الاجاج والمفرخات في مصر. \\ مريم حسين شكرى" ، إسماعيل عبد الحفيظر رضوان ** ، وفاء عبد الغني عبد الغني**** ومحمد محروس عامر ****

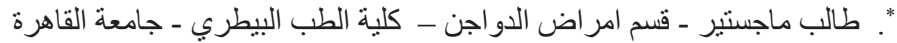

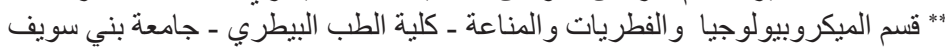

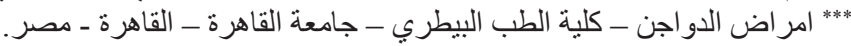

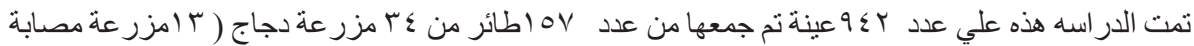

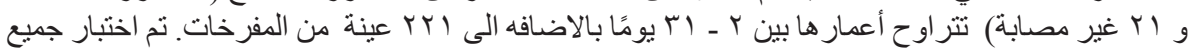

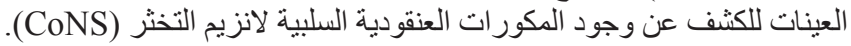

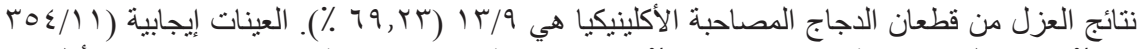

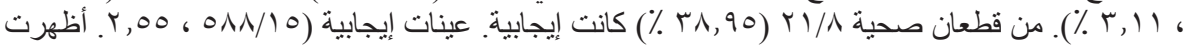

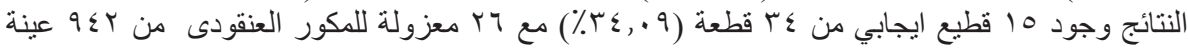

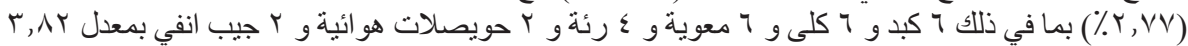





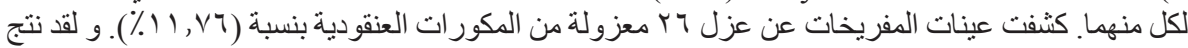

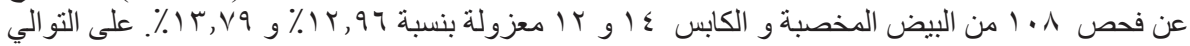

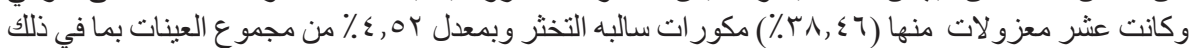

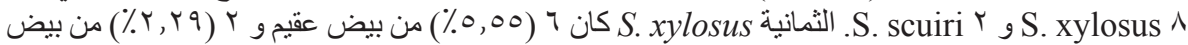

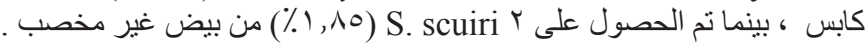

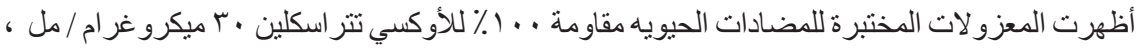

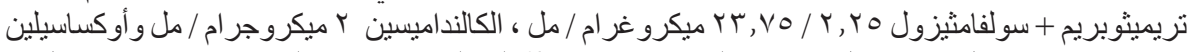

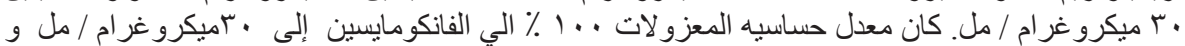

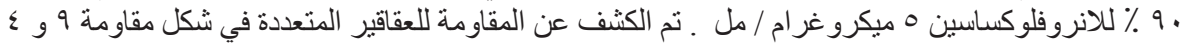

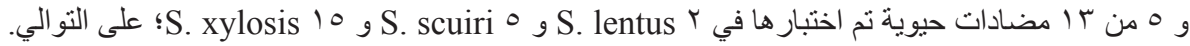

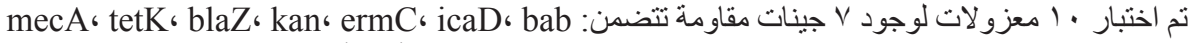

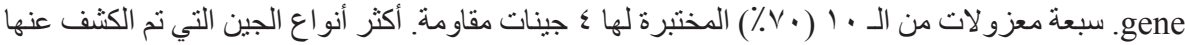

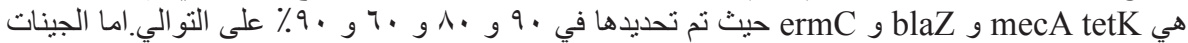
bab gens gan ، icaD

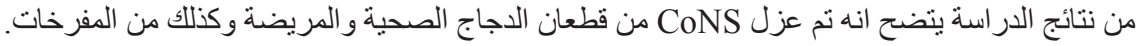



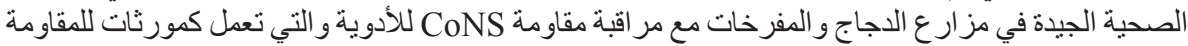

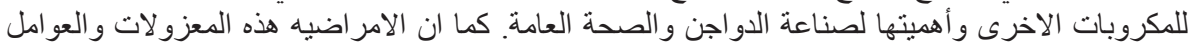

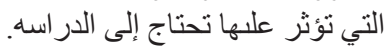

